\title{
Article \\ Modelling of the Steel High-Temperature Deformation Behaviour Using Artificial Neural Network
}

\author{
Alexander Churyumov ${ }^{1, * \mathbb{C}}$, Alena Kazakova ${ }^{1}$ and Tatiana Churyumova ${ }^{2}$ \\ 1 Department of Physical Metallurgy of Non-Ferrous Metals, National University of Science and Technology \\ "MISiS", Leninskiy Prospekt 4, 119049 Moscow, Russia; m1805037@edu.misis.ru \\ 2 Joint-Stock Company "Advanced Research Institute of Inorganic Materials named after Academician A.A. \\ Bochvar", Rogova Str. 5a, 123098 Moscow, Russia; tachuryumova@bochvar.ru \\ * Correspondence: churyumov@misis.ru; Tel.: +7-495-955-0134
}

check for updates

Citation: Churyumov, A.; Kazakova, A.; Churyumova, T. Modelling of the Steel High-Temperature Deformation Behaviour Using Artificial Neural Network. Metals 2022, 12, 447. https://doi.org/10.3390/ met12030447

Academic Editor: Iztok Peruš

Received: 31 January 2022

Accepted: 1 March 2022

Published: 4 March 2022

Publisher's Note: MDPI stays neutral with regard to jurisdictional claims in published maps and institutional affiliations.

Copyright: (c) 2022 by the authors. Licensee MDPI, Basel, Switzerland. This article is an open access article distributed under the terms and conditions of the Creative Commons Attribution (CC BY) license (https:// creativecommons.org/licenses/by/ $4.0 /)$.

\begin{abstract}
Hot forming is an essential part of the manufacturing of most steel products. The hot deformation behaviour is determined by temperature, strain rate, strain and chemical composition of the steel. To date, constitutive models are constructed for many steels; however, their specific chemical composition limits their application. In this paper, a novel artificial neural network (ANN) model was built to determine the steel flow stress with high accuracy in the wide range of the concentration of the elements in high-alloyed, corrosion-resistant steels. The additional compression tests for stainless $\mathrm{Cr} 12 \mathrm{Ni3Cu}$ steel were carried out at the strain rates of $0.1-10 \mathrm{~s}^{-1}$ and the temperatures of 900-1200 ${ }^{\circ} \mathrm{C}$ using thermomechanical simulator Gleeble 3800. The ANN-based model showed high accuracy for both training (the error was $6.6 \%$ ) and approvement (11.5\%) datasets. The values of the effective activation energy for experimental $(410 \pm 16 \mathrm{~kJ} / \mathrm{mol})$ and predicted peak stress values $(380 \pm 29 \mathrm{~kJ} / \mathrm{mol})$ are in good agreement. The implementation of the constructed ANN-based model showed a significant influence of the $\mathrm{Cr} 12 \mathrm{Ni} 3 \mathrm{Cu}$ chemical composition variation within the grade on the flow stress at a steady state of the hot deformation.
\end{abstract}

Keywords: hot deformation; artificial neural network; thermomechanical simulator gleeble; $\mathrm{Cr} 12 \mathrm{Ni3} \mathrm{Cu}$ steel; constitutive model

\section{Introduction}

Despite the stable development of new metallurgical directions such as additive manufacturing [1,2], amorphous [3,4] and composite structuring [5,6] technologies, the majority of critical steel products in the nuclear industry in the coming decades will be manufactured using the traditional scheme, including steel melting and casting, hot and cold plastic deformation and mechanical and heat treatment [7-9]. However, the requirements for the microstructure and properties of the materials will be permanently increased. In this regard, the optimisation of the chemical composition and manufacturing technologies of the steels is required.

Hot deformation is one of the important manufacturing stages. The hot deformation behaviour is significantly influenced not only by the deformation conditions such as temperature, strain rate and strain but also by the chemical composition of the steel. The investigation and modelling of the hot deformation behaviour are necessary to optimise the forming technologies using finite element simulation [10,11]. Most of the constitutive models were constructed for materials with specific chemical compositions. At the last time, models were constructed for the low-carbon [12], reduced activation ferritic/martensitic [13] and 1.4542 stainless [14] steels. However, even minor deviations within the same grade can lead to significant changes in rheological properties. To date, there are no physical and mathematical models linking these characteristics directly with the chemical composition. The reason is a large number of alloying elements in industrial steel, which does not allow revealing the complex effect of alloying elements on hot deformation behaviour. 
Unfortunately, limited human capabilities do not allow for analysing big data of properties such complex objects as industrial steel. The problem may be solved by machine learning, implemented through artificial neural networks (ANN).

The ANN provides a way to predict functional dependences without preliminary known laws. Such a method shows a minimum calculation error; however, it requires a big set of experimental data. Liu et al. have shown a high accuracy ANN-based model for the determination of the $42 \mathrm{CrMo}$ steel hot flow behaviour compared to the Arrhenius-type model [15]. Similar results were obtained by other scholars for API 5CT-L80 [16], AISI1045 [17], 9Cr-1Mo [18], 10Cr [19], 40Mn [20] and 33Cr23Ni8Mn3N [21] steels. K. Arun Babu et al. have constructed a dynamic recrystallisation model in super austenitic stainless steel [22] using an ANN-based approach. However, all the authors have used ANN-based modelling for the steels with a specific composition and have not used the ability of the ANN to find the dependences of the hot deformation behaviour on the alloying elements concentration.

The purpose of the investigation is the construction and approbation of the ANN-based model relating rheological properties with the chemical composition and hot deformation parameters of high-alloyed, corrosion-resistant steels.

\section{Materials and Methods}

\subsection{ANN Construction}

The database of the hot deformation rheological properties of the steels with different chemical compositions was collected to build the ANN-based model [23-59]. The ranges of the alloying elements concentrations and the deformation conditions in the database are presented in Table 1. The overall number of entries in the database was 7912. The dataset was randomly mixed and divided into three groups: the group for the training of the ANN (60\% of the dataset), the cross-validation data $(20 \%)$ and the testing entries $(20 \%)$. The hyperbolic tangent function was used as a transfer function in all neurons. The strain, deformation temperature, strain rate and concentrations of the alloying elements were chosen as inputs variables and the flow stress as an output of the model. The architecture of the ANN is presented in Figure 1. The model's training was made by the static backpropagation algorithm using NeuroSolution software. The number of neurons was proposed by the NeuroSolution. However, it fully follows the formula proposed by G. Lachtermacher and G. Fuller [60]:

$$
\frac{0.11 P}{I+1} \leq N \leq \frac{0.11 P}{I+1}
$$

where $I$ is the number of input parameters; $P$ is the amount of data used for ANN training. The formulas and the coefficients for using the constructed ANN-based model are presented in the Supplementary Materials.

Table 1. The ranges of the alloying elements concentration, deformation temperatures, strain rates and strains in the database (wt. \%).

\begin{tabular}{|c|c|c|c|c|c|c|c|c|}
\hline $\mathrm{C}$ & $\mathrm{Si}$ & Mn & $\mathrm{Cr}$ & $\mathrm{Ni}$ & $\mathrm{Cu}$ & Mo & $\mathbf{V}$ & $\mathbf{N}$ \\
\hline 0-0.19 & $0-2.2$ & $0-2.06$ & $0-28$ & $0-33$ & $0-1.96$ & $0-5.06$ & $0-1.25$ & $0-0.041$ \\
\hline Ta & $\mathbf{W}$ & $\mathrm{Nb}$ & Al & \multicolumn{2}{|c|}{ Temperature, ${ }^{\circ} \mathrm{C}$} & \multicolumn{2}{|c|}{ Strain rate, $\mathrm{s}^{-1}$} & Strain \\
\hline $0-0.097$ & $0-2.37$ & $0-1.1$ & $0-2.6$ & \multicolumn{2}{|c|}{$700-1250$} & \multicolumn{2}{|c|}{$10^{-4}-50$} & $0-1.3$ \\
\hline
\end{tabular}




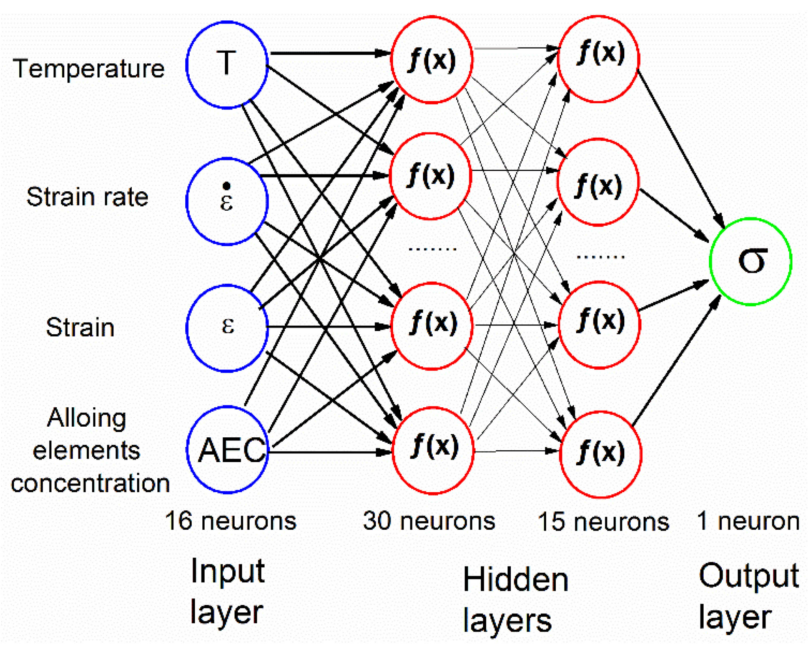

Figure 1. The structure of the constructed ANN.

\subsection{Additional Compression Tests for ANN-Based Model Approbation}

The additional hot compression tests of the $13 \mathrm{Cr} 3 \mathrm{NiCu}$ steel were carried out to approve the workability of the constructed model. This steel belongs to stainless and cavitation-resistant chromium steels. The level of Ni concentration is sufficient for forming a martensitic microstructure during the quenching even of massive products. The industrial technology of hot forming of the $13 \mathrm{Cr} 3 \mathrm{NiCu}$ steel ingots consists of eight more hot deformation stages. Therefore, it is very important to precisely determine the steel's hot deformation behaviour to optimise the forming technology.

The ingots of the steel were obtained by vacuum induction melting with raw materials of commercial purity. The nominal chemical composition of the alloy is presented in Table 2. Cast ingots with a diameter of $250 \mathrm{~mm}$ and a height of $500 \mathrm{~mm}$ were annealed for $8 \mathrm{~h}$ at the temperature of $1200{ }^{\circ} \mathrm{C}$ and then were pressed with the deformation rate of $0.01 \mathrm{~mm} / \mathrm{s}$ to the strain of $60 \%$ at the temperature of $1200{ }^{\circ} \mathrm{C}$. The samples for the compression test were cut in the pressing direction.

Table 2. Chemical composition of the $13 \mathrm{Cr} 3 \mathrm{NiCu}$ steel (wt. \%).

\begin{tabular}{ccccccc}
\hline $\mathbf{C}$ & $\mathbf{S i}$ & $\mathbf{M n}$ & $\mathbf{C r}$ & $\mathbf{N i}$ & $\mathbf{C u}$ & $\mathbf{F e}$ \\
\hline 0.05 & 0.2 & 0.4 & 12.2 & 3.1 & 1.1 & Balance \\
\hline
\end{tabular}

Axisymmetric compression tests were performed using a Gleeble 3800 thermomechanical simulator (Figure 2). The specimens with a diameter of $10 \mathrm{~mm}$ and a height of $15 \mathrm{~mm}$ were heated at a rate of $5^{\circ} \mathrm{C} / \mathrm{s}$ to the deformation temperature $(900,980,1050,1130$ and $1200{ }^{\circ} \mathrm{C}$ ), held for $2 \mathrm{~min}$ and compressed in a single hit to a true strain of 1.3 at a constant true strain rate of $0.1,1$ and $10 \mathrm{~s}^{-1}$. The true stress-strain curves were treated to consider the friction and adiabatic heating during the deformation [61,62]. The error of the stress determination using Gleeble is low because of the high accuracy temperature and strain rate control. Due to this fact, only one sample for each hot compression condition was used for obtaining the stress-strain curve. To approve the reproducibility of the compression tests, we repeat two more times the compression at the temperature of $1050{ }^{\circ} \mathrm{C}$ and the strain rate of $1 \mathrm{~s}^{-1}$. As shown in Figure A1 (Appendix A), the reproducibility of Gleeble tests is high. The error is increased only at high strain values due to potential significant differences in friction conditions. 


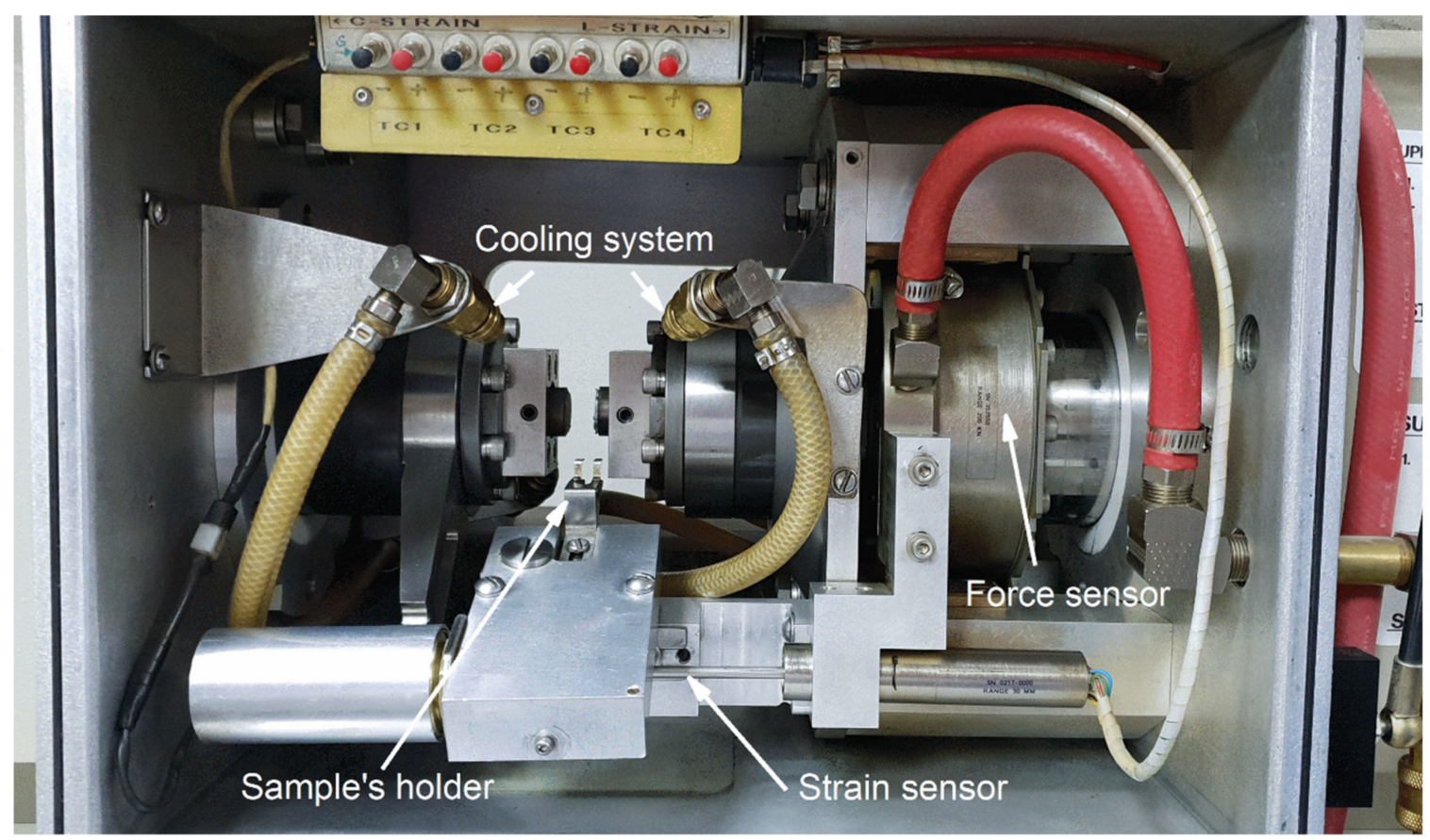

Figure 2. The image of the camera of the Gleeble 3800 system.

A Tescan-VEGA3 LMH scanning electron microscope (SEM) was used for the initial microstructural investigation. Thermodynamic calculations of high-temperature phase states were carried out using Thermocalc software with TCFe7 database.

\section{Results}

\subsection{Results of ANN Modelling}

Results of the calculations using the ANN-based model are presented in Figure 3. The accuracy of the model was determined using average relative error (ARE) and Pearson's correlation coefficient $(R)[63]$ :

$$
\begin{gathered}
\operatorname{ARE}(\%)=\frac{100}{N} \sum_{i=1}^{N} \frac{\left|E_{i}-P_{i}\right|}{E_{i}} \\
R=\frac{\sum_{i=1}^{N}\left(E_{i}-\overline{\bar{E}}\right)\left(P_{i}-\bar{P}\right)}{\sqrt{\sum_{i=1}^{N}\left(E_{i}-\overline{\bar{E}}\right)^{2} \sum_{i=1}^{N}\left(P_{i}-\bar{P}\right)^{2}}}
\end{gathered}
$$
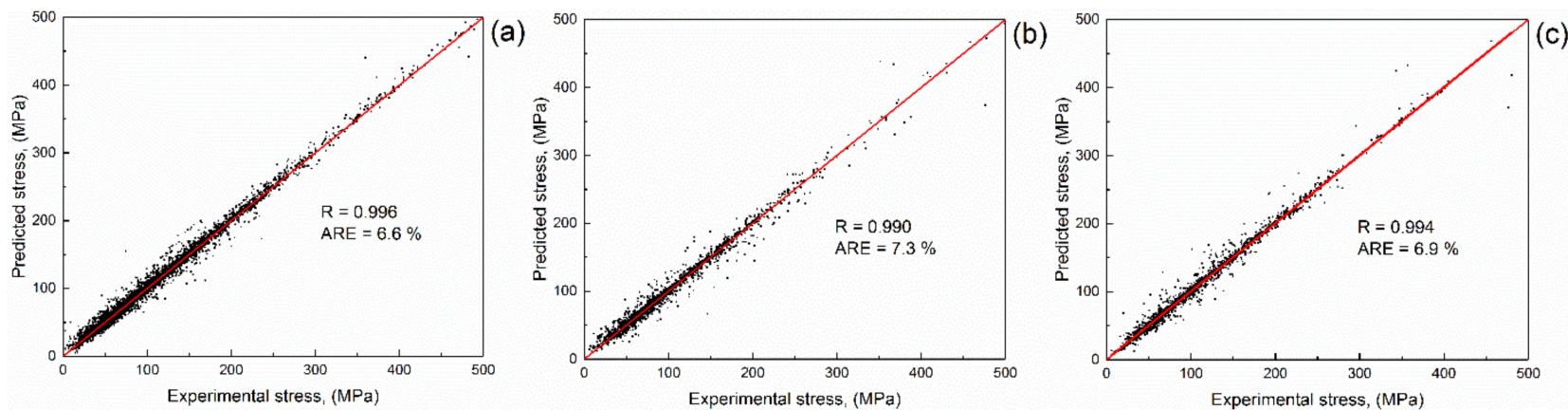

Figure 3. A comparison between predicted using ANN-based model and experimental stress values for (a) training, (b) cross-validation and (c) testing datasets. 
Here, $E, P, \overline{\bar{E}}$ and $\bar{P}$ are the experimental, predicted stress and those mean values, correspondently. $N$ is the number of entries in the dataset.

The ARE has a $6.6-7.3 \%$ value for all datasets. Such a low error and a high Pearson's correlation coefficient value show the constructed model's good accuracy. However, the presented results show the model's accuracy only for the hot deformation curves used for the ANN teaching, and an additional independent check is required.

\subsection{Initial Microstructure and Hot Deformation Behaviour of the $13 \mathrm{Cr} 3 \mathrm{NiC}$ Steel}

Additional hot deformation tests were carried out to check the accuracy of the constructed ANN-based model. Figure 4a shows an initial microstructure of the investigated steel. The microstructure consists of lath martensite with an average grain size of $10 \pm 2.6 \mu \mathrm{m}$. Accordingly thermodynamic calculations, the microstructure of the investigated steel at elevated temperatures may contain austenite (fcc), ferrite (bcc), carbide $\left(\mathrm{M}_{23} \mathrm{C}_{6}\right)$ and liquid phases (Figure $\left.4 \mathrm{~b}\right)$. In the current investigation, the deformation of the steel was carried out in the austenitic region.
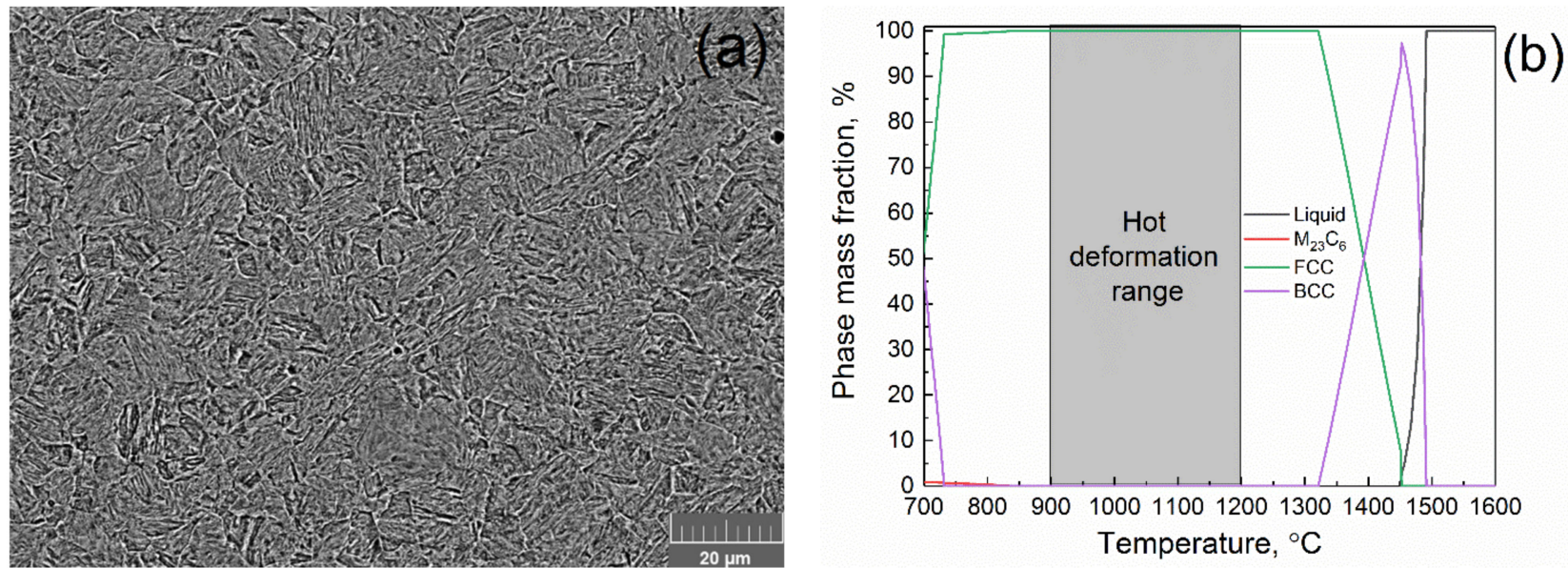

Figure 4. Initial microstructure (a) and high-temperature phase composition (b) of $12 \mathrm{Cr} 3 \mathrm{NiCu}$ steel.

The typical true stress-true strain curves of the $12 \mathrm{Cr} 3 \mathrm{NiCu}$ steel are shown in Figure 5a,b. The steel demonstrates a usual hot deformation response to the change of the testing conditions: the stress increases with a strain rate rise and decreases with a temperature increase. Moreover, the true stress achieves a maximum value on the curve at all deformation conditions. The softening after peak proceeds due to the dominance of the dynamic recovery and recrystallisation of the work hardening during the deformation. The stress-strain curves reach a steady state at temperatures higher than $1050{ }^{\circ} \mathrm{C}$. At lower temperatures, the process of dynamic recrystallisation does not finish despite a large strain value of 1.3.

\subsection{Approbation of the ANN-Based Model}

A comparison between calculated and experimental stress-strain curves for the $12 \mathrm{Cr} 3 \mathrm{NiCu}$ steel is shown in Figure 6a-c. The ARE of the ANN-based model for the additional hot deformation test was $11.5 \%$. The maximum values of ARE up to $40 \%$ were obtained at lower hot deformation temperatures (lower than $980^{\circ} \mathrm{C}$ ) and the high strain value. However, in the range of the temperatures of $1050-1200^{\circ} \mathrm{C}$, the ANN-based model shows very high accuracy for most of the deformation conditions, allowing the analysis of the influence of different factors on the true stress value. 

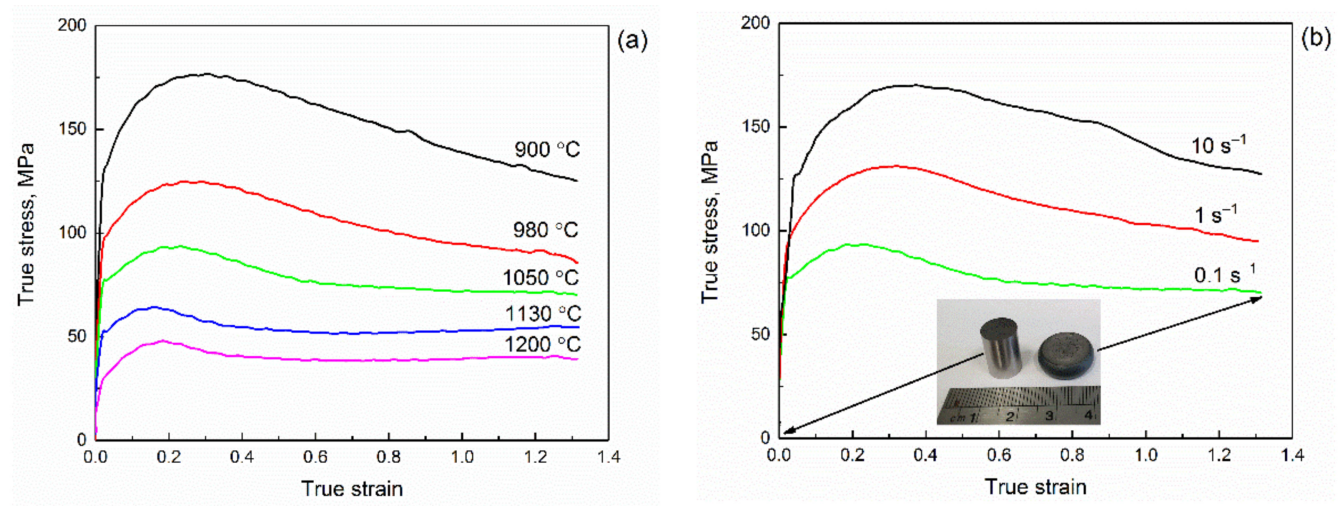

Figure 5. Hot compression curves for the $12 \mathrm{Cr} 3 \mathrm{NiCu}$ steel at a strain rate of $0.1 \mathrm{~s}^{-1}$ (a) and at a temperature of $1050{ }^{\circ} \mathrm{C}(\mathbf{b})$. The image of the samples before and after compression (inset on (b)).
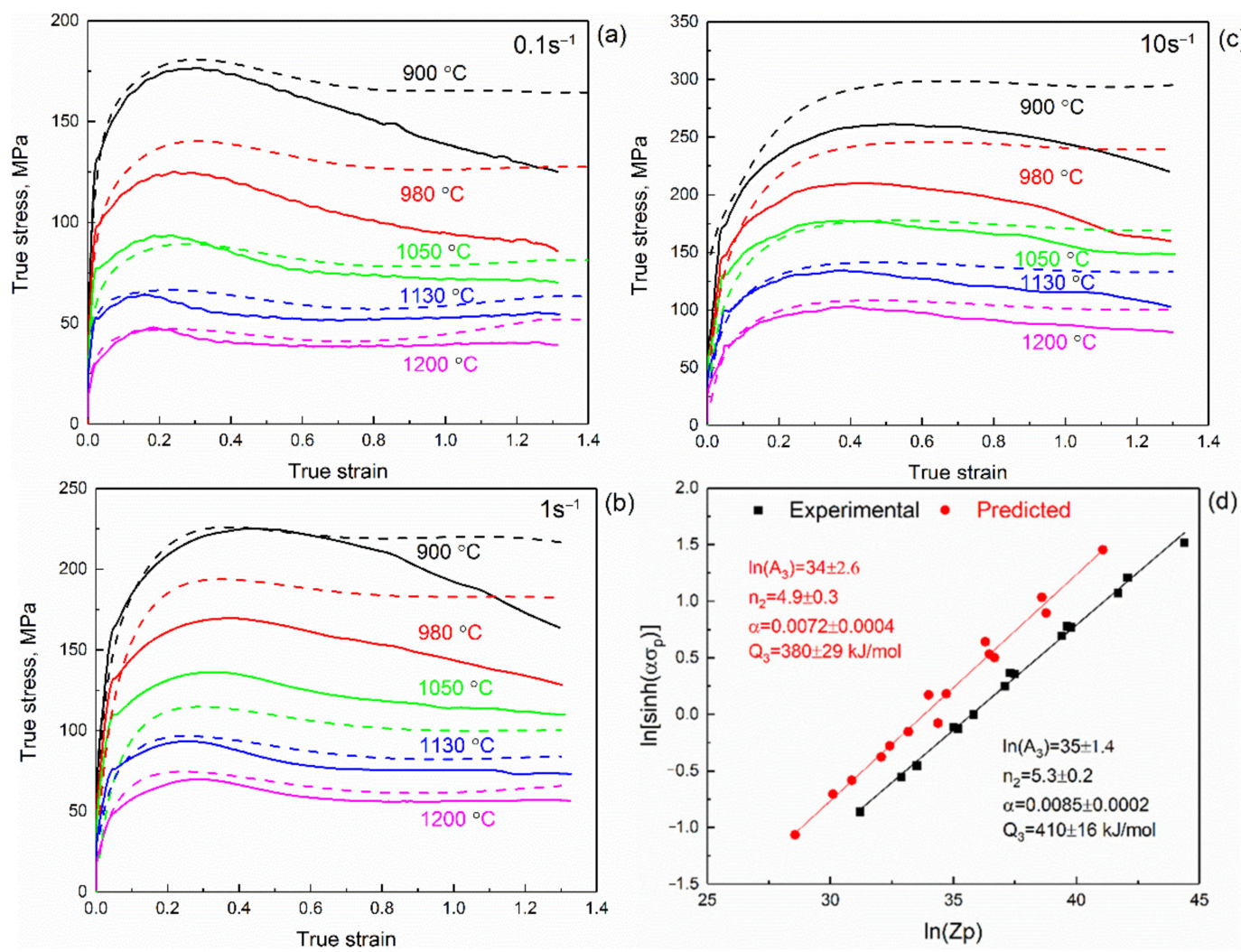

Figure 6. A comparison of the experimental and predicted hot deformation curves for the $12 \mathrm{Cr} 3 \mathrm{NiCu}$ steel at a strain rate of $0.1 \mathrm{~s}^{-1}(\mathbf{a}), 1 \mathrm{~s}^{-1}(\mathbf{b})$ and $10 \mathrm{~s}^{-1}(\mathbf{c})$. The $\ln \left[\sinh \left(\alpha \sigma_{p}\right)\right] \mathrm{vs} . \ln \left(Z_{p}\right)(\mathbf{d})$.

The correlation between the experimental $\left(\sigma_{p}^{e x p}\right)$ and predicted $\left(\sigma_{p}^{p r}\right)$ peak stress was checked by constitutive modelling using the Zener-Hollomon parameter [64]:

$$
Z=\dot{\varepsilon} e^{\frac{Q}{R T}},
$$

where $\dot{\varepsilon}$ is the strain rate $\left(\mathrm{s}^{-1}\right), \mathrm{T}$ is the temperature $(\mathrm{K})$ and $Q$ is the apparent effective activation energy $(\mathrm{J} / \mathrm{mol})$. The relationship between the hot deformation response and $Z$ may be described by the following sets of equations:

$$
\begin{gathered}
Z=A_{3}\left[\sinh \left(\alpha \sigma_{p}\right)\right]^{n_{2}} \text { for all } \sigma_{p} \\
Z=A_{1} \sigma_{p}^{n_{1}}, \text { if } \alpha \sigma_{p}<0.8
\end{gathered}
$$




$$
Z=A_{2} e^{\beta \sigma_{p}}, \text { if } \alpha \sigma_{p}>1.2
$$

The stress multiplier $\alpha$ can be described as follows:

$$
\alpha \approx \frac{\beta}{n_{1}}
$$

The material constants $A_{1}, A_{2}, A_{3}, n_{1}, n_{2}, \beta, \alpha$ and $Q$ were determined using the least square method. The comparison of the constitutive models is shown in Figure $6 \mathrm{~d}$. The values of the effective activation energy for experimental and predicted stresses are in good correspondence within the confidence interval, which shows a high accuracy of the constructed model for the prediction of the hot deformation behaviour.

\section{Discussion}

The difference between experimental and calculated stress-strain curves for low deformation temperatures and high strain values is larger than the experimental error of the Gleeble testing. However, for industrial hot deformation processes, high temperatures and strain below 1 are usually used. The error of the constructed ANN-based model in such conditions is significantly lower, and its accuracy is enough for the prediction of the flow stress and optimisation of the hot deformation technology.

The constructed model was used to determine the possible influence of chemical composition variations of the $12 \mathrm{Cr} 3 \mathrm{NiCu}$ steel within the grade (Table 3 ) on the stress value. As shown in Figure 7, the true stress value may be significantly influenced by changing the alloying elements' concentration. Increasing the $\mathrm{Ni}$ and $\mathrm{Cr}$ concentrations from low to high limit leads to a rise of the flow stress on 20-30 MPa dependently on the deformation temperature. Copper influences more intensively on the stress and may change its value on $90 \mathrm{MPa}$ at a deformation temperature of $1150{ }^{\circ} \mathrm{C}$. A similar result was previously obtained experimentally by Li et al. [65]: adding copper to 304L stainless steel significantly decreased the true stress due to increasing the stacking fault energy and, consequently, inhibiting the dynamic recrystallisation. Previously, the significant influence of the minor variations of the 25CrMo steel chemical composition on the hot fracture behaviour was shown by Zheng et al. [66]. The changes in the mechanical properties of the hot-deformed low-carbon microalloyed steels with the change of the chemical composition within the steel grade were also shown in [67]. However, information about the significant influence of the minor chemical composition changes on the hot deformation behaviour was not shown for high-alloyed, corrosion-resistant steel.

Table 3. Variation of the concentration of the alloying elements within the $13 \mathrm{Cr} 3 \mathrm{NiCu}$ steel grade (wt. \%).

\begin{tabular}{ccccccc}
\hline $\mathbf{C}$ & $\mathbf{S i}$ & $\mathbf{M n}$ & $\mathbf{C r}$ & $\mathbf{N i}$ & $\mathbf{C u}$ & $\mathbf{F e}$ \\
\hline$\leq 0.06$ & $\leq 0.3$ & $\leq 0.6$ & $11.8-13.7$ & $2.7-3.3$ & $0.8-1.1$ & Balance \\
\hline
\end{tabular}

Even concentration of the one element may change the deformation response of the steel. However, during the steel melting process, all the concentrations may achieve the grade limits, which significantly changes the flow stress. Pair influences of the different alloying elements on the flow stress of the $12 \mathrm{Cr} 3 \mathrm{NiCu}$ steel at a steady state during the deformation at a strain rate of $1 \mathrm{~s}^{-1}$ and a temperature of $1130{ }^{\circ} \mathrm{C}$ are shown in Figure 8 . As seen, maximum differences in true stress in pairs $\mathrm{Cr}-\mathrm{Ni}, \mathrm{Cr}-\mathrm{Cu}$ and $\mathrm{Ni}-\mathrm{Cu}$ are 30 ( $\pm 20 \%$ of average experimental stress value in Figure $8 \mathrm{~b}), 33( \pm 22 \%)$ and $57 \mathrm{MPa}( \pm 38 \%)$, correspondently, which may sufficiently influence the hot deformation in the industrial conditions. 

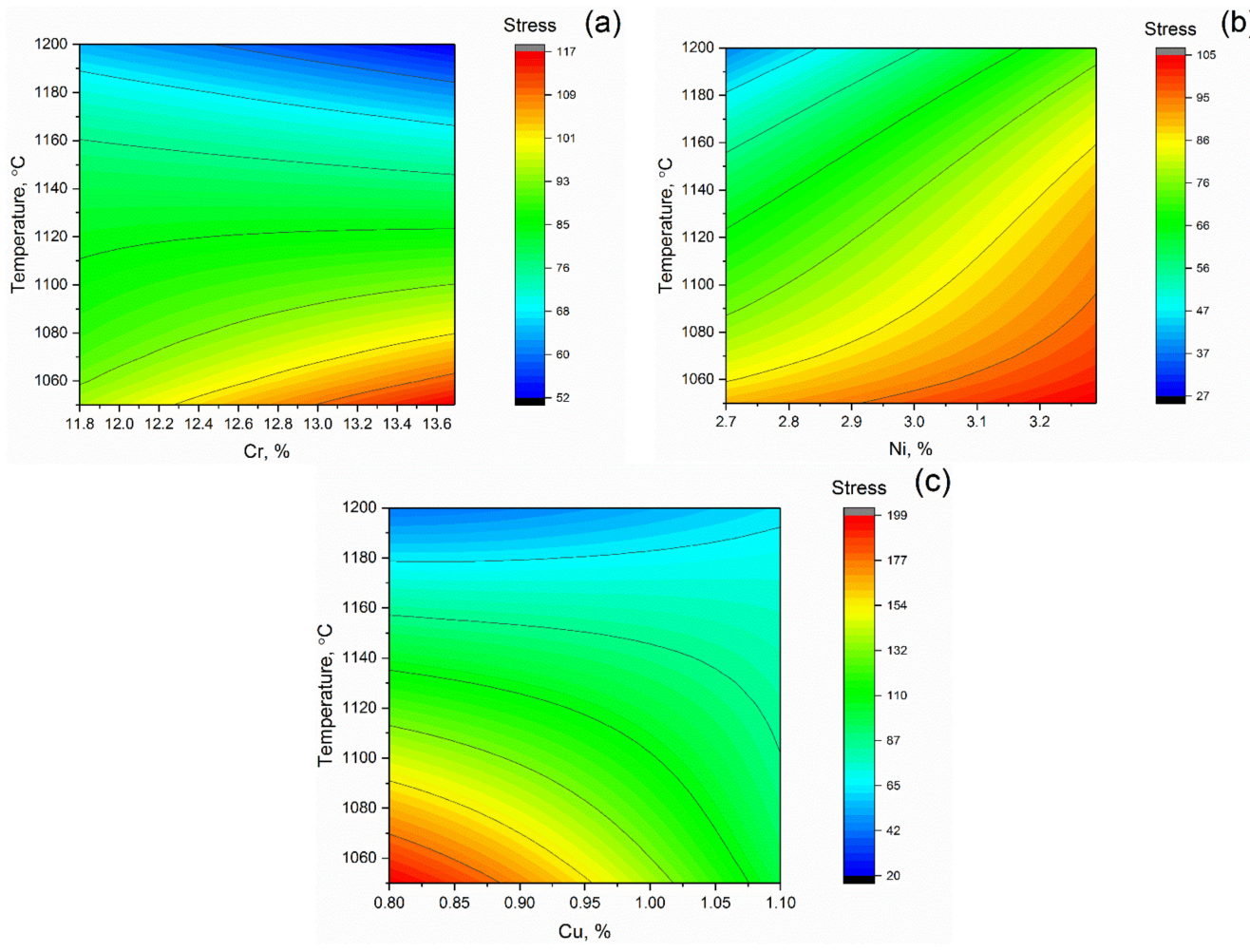

Figure 7. Calculated values of the $12 \mathrm{Cr} 3 \mathrm{NiCu}$ steel true stress at steady state (a strain of 1 ) at a strain rate of $1 \mathrm{~s}^{-1}$ at different temperatures and concentrations of $\mathrm{Cr}(\mathbf{a}), \mathrm{Ni}(\mathbf{b})$ and $\mathrm{Cu}(\mathbf{c})$.
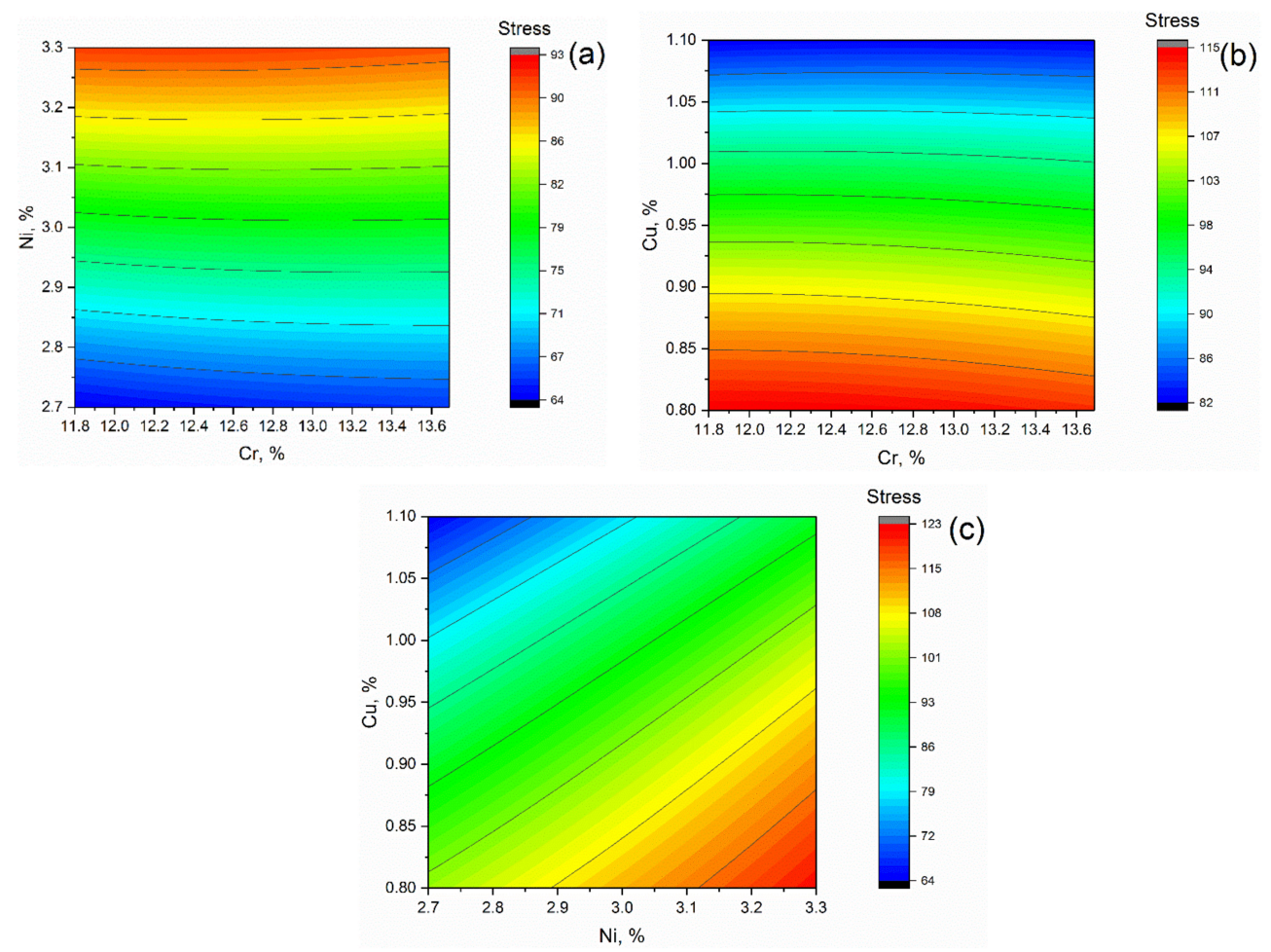

Figure 8. Dependence of the $12 \mathrm{Cr} 3 \mathrm{NiCu}$ steel true stress at steady state (a strain of 1 ) on $\mathrm{Cr}$ and $\mathrm{Ni}(\mathbf{a})$, $\mathrm{Cr}$ and $\mathrm{Cu}(\mathbf{b})$ and $\mathrm{Ni}$ and $\mathrm{Cu}(\mathbf{c})$ concentrations at a strain rate of $1 \mathrm{~s}^{-1}$ and a temperature of $1130{ }^{\circ} \mathrm{C}$.

The presented approach of the ANN-based model construction and approvement may be useful for modelling the hot deformation behaviour not only for different groups of 
steels but also for other metallic material such as magnesium, aluminium and titanium alloy due to a large number of published experimental data and the increased computational possibility of the computers. Besides, the constructed models may be applied not only to optimise the industrial processes but also let to find the dependencies between hightemperature response and the microstructure by coupling the developed approach with the thermodynamic calculations.

\section{Conclusions}

1. An artificial neural network model for predicting flow stress of the high-alloyed, corrosion-resistant steel during the hot deformation was constructed. The model shows high accuracy for the training and testing datasets. An average relative error is in the range of $6.6-7.3 \%$.

2. The other series of hot compression tests of the $12 \mathrm{Cr} 3 \mathrm{NiCu}$ steel was carried out to approve the predictability of the constructed ANN-based model. The comparison of the experimental and predicted stress-strain curves shows a high model accuracy at temperatures higher than $1050{ }^{\circ} \mathrm{C}$ at all investigated strain rates.

3. The constitutive models for predicted and experimental peak stress values were constructed using the Zener-Hollomon parameter. Obtained values of the effective activation energy for experimental $(410 \pm 16 \mathrm{~kJ} / \mathrm{mol})$ and predicted data $(380 \pm 29 \mathrm{~kJ} / \mathrm{mol})$ are in good agreement that allow the use of constructed ANN-based model for analysis of the steel's hot deformation behaviour.

4. The approbation of the constructed model shows that the hot deformation behaviour may be significantly influenced by the fluctuation of the chemical composition within the grade of the steel. Usage of the ANN-based model allows for optimisation of the industrial hot deformation technology depending on the real chemical composition of the steel.

Supplementary Materials: The following supporting information can be downloaded at: https: / / www.mdpi.com/article/10.3390/met12030447/s1. Table S1. The values of the neuron's biases in the hidden layers. Table S2. The values of the synapses between $j$-th neuron in the first hidden layer and $i$-th input parameter $(w 1 h)$. Table S3. The synapse values between $k$-th neuron in the second hidden layer and $j$-th neuron in the first hidden layer $(w 2 h)$.

Author Contributions: Conceptualization, A.C.; methodology, A.C.; validation, A.C. and T.C.; investigation, A.K.; resources, A.C.; data curation, T.C.; writing-original draft preparation, A.C.; supervision, A.C.; project administration, A.C.; funding acquisition, A.C. All authors have read and agreed to the published version of the manuscript.

Funding: This research was funded by the Russian Science Foundation (project №18-79-10153-P).

Institutional Review Board Statement: Not applicable.

Informed Consent Statement: Not applicable.

Data Availability Statement: Data is contained within the article and Supplementary Materials.

Conflicts of Interest: The authors declare no conflict of interest. 


\section{Appendix A}

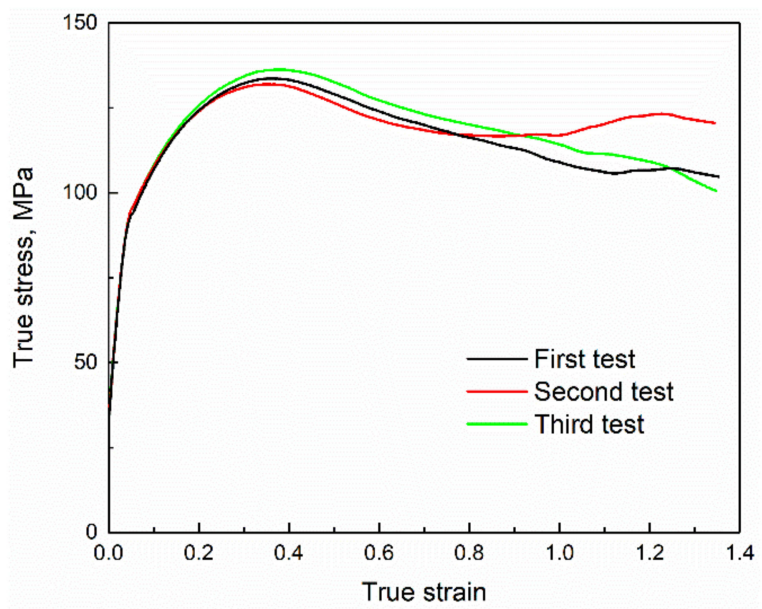

Figure A1. The comparison of the stress-strain curves of three samples test at the temperature of $1050{ }^{\circ} \mathrm{C}$ and the strain rate of $1 \mathrm{~s}^{-1}$.

\section{References}

1. Eftink, B.P.; Vega, D.A.; El Atwani, O.; Sprouster, D.J.; Yoo, Y.S.J.; Steckley, T.E.; Aydogan, E.; Cady, C.M.; Al-Sheikhly, M.; Lienert, T.J.; et al. Tensile properties and microstructure of additively manufactured Grade 91 steel for nuclear applications. J. Nucl. Mater. 2021, 544, 152723. [CrossRef]

2. Moskvina, V.A.; Melnikov, E.V.; Astafurov, S.V.; Panchenko, M.Y.; Reunova, K.A.; Kolubaev, E.A.; Astafurova, E.G. Stable high-nickel austenitic steel produced by electron beam additive manufacturing using dual wire-feed system. Mater. Lett. 2021, 305, 130863. [CrossRef]

3. Alsmadi, Z.Y.; Bourham, M.A. An assessment of protective coating dry cask canisters with structurally amorphous metals (SAMs) for enhanced radiation shielding. Nucl. Eng. Des. 2022, 388, 111647. [CrossRef]

4. Alshahrani, B.; Olarinoye, I.O.; Mutuwong, C.; Sriwunkum, C.; Yakout, H.A.; Tekin, H.O.; Al-Buriahi, M.S. Amorphous alloys with high Fe content for radiation shielding applications. Radiat. Phys. Chem. 2021, 183, 109386. [CrossRef]

5. Seils, S.; Kauffmann, A.; Delis, W.; Boll, T.; Heilmaier, M. Microstructure and mechanical properties of high-Mn-ODS steels. Mater. Sci. Eng. A 2021, 825, 141859. [CrossRef]

6. Doñate-Buendia, C.; Kürnsteiner, P.; Stern, F.; Wilms, M.B.; Streubel, R.; Kusoglu, I.M.; Tenkamp, J.; Bruder, E.; Pirch, N.; Barcikowski, S.; et al. Microstructure formation and mechanical properties of ODS steels built by laser additive manufacturing of nanoparticle coated iron-chromium powders. Acta Mater. 2021, 206, 116566. [CrossRef]

7. Francis, R.; Byrne, G. Duplex stainless steels-Alloys for the 21st century. Metals 2021, 11, 836. [CrossRef]

8. Li, X.; Gao, F.; Jiao, J.; Cao, G.; Wang, Y.; Liu, Z. Influences of cooling rates on delta ferrite of nuclear power $316 \mathrm{H}$ austenitic stainless steel. Mater. Charact. 2021, 174, 111029. [CrossRef]

9. Griffin, P.W.; Hammond, G.P. The prospects for 'green steel' making in a net-zero economy: A UK perspective. Glob. Transit. 2021, 3, 72-86. [CrossRef]

10. Teker, E.; Danish, M.; Gupta, M.K.; Kuntoğlu, M.; Korkmaz, M.E. Hot Deformation Behavior and Strain Rate Sensitivity of 33MnCrB5 Boron Steel Using Material Constitutive Equations. Trans. Indian Inst. Met. 2022, 75, 717-726. [CrossRef]

11. Renault, C.; Churyumov, A.Y.; Pozdniakov, A.V.; Churyumova, T.A. Microstructure and hot deformation behavior of FeMnAlCMo steel. J. Mater. Res. Technol. 2020, 9, 4440-4449. [CrossRef]

12. Li, C.; Zhang, L.; Li, F.; Zhang, C.; Mao, P. Constitutive Modeling of Flow Behavior and Processing Maps of a Low-Carbon Steel. J. Mater. Eng. Perform. 2022, 31, 895-906. [CrossRef]

13. Liu, G.; Mao, C.; Ding, R.; Yu, L.; Liu, C.; Liu, Y. The kinetics of dynamic recrystallization and construction of constitutive modeling of RAFM steel in the hot deformation process. J. Nucl. Mater. 2021, 557, 153285. [CrossRef]

14. Motlagh, Z.S.; Tolaminejad, B.; Momeni, A. Prediction of Hot Deformation Flow Curves of 1.4542 Stainless Steel. Met. Mater. Int. 2021, 27, 2512-2529. [CrossRef]

15. Liu, H.; Cheng, Z.; Yu, W.; Wang, G.; Zhou, J.; Cai, Q. Deformation behavior and constitutive equation of $42 \mathrm{crmo}$ steel at high temperature. Metals 2021, 11, 1614. [CrossRef]

16. Ahmadi, H.; Rezaei Ashtiani, H.R.; Heidari, M. A comparative study of phenomenological, physically-based and artificial neural network models to predict the Hot flow behavior of API 5CT-L80 steel. Mater. Today Commun. 2020, 25, 101528. [CrossRef]

17. Murugesan, M.; Sajjad, M.; Jung, D.W. Hybrid machine learning optimization approach to predict hot deformation behavior of medium carbon steel material. Metals 2019, 9, 1315. [CrossRef] 
18. Kumar, S.; Karmakar, A.; Nath, S.K. Construction of hot deformation processing maps for 9Cr-1Mo steel through conventional and ANN approach. Mater. Today Commun. 2021, 26, 101903. [CrossRef]

19. Shokry, A.; Gowid, S.; Kharmanda, G.; Mahdi, E. Constitutive models for the prediction of the hot deformation behavior of the 10\%Cr steel alloy. Materials 2019, 12, 2873. [CrossRef]

20. Huang, W.; Lei, L.; Fang, G. Comparison Between Four Flow Stress Models Characterizing the Constitutive Behavior of Hot Deformation of 40Mn Steel. J. Mater. Eng. Perform. 2021, 30, 9149-9164. [CrossRef]

21. Cai, Z.; Ji, H.; Pei, W.; Wang, B.; Huang, X.; Li, Y. Constitutive equation and model validation for 33Cr23Ni8Mn3N heat-resistant steel during hot compression. Results Phys. 2019, 15, 102633. [CrossRef]

22. Arun Babu, K.; Prithiv, T.S.; Gupta, A.; Mandal, S. Modeling and simulation of dynamic recrystallization in super austenitic stainless steel employing combined cellular automaton, artificial neural network and finite element method. Comput. Mater. Sci. 2021, 195, 110482. [CrossRef]

23. Wang, W.T.; Guo, X.Z.; Huang, B.; Tao, J.; Li, H.G.; Pei, W.J. The flow behaviors of CLAM steel at high temperature. Mater. Sci. Eng. A 2014, 599, 134-140. [CrossRef]

24. Churyumov, A.Y.; Medvedeva, S.V.; Mamzurina, O.I.; Kazakova, A.A.; Churyumova, T.A. United Approach to Modelling of the Hot Deformation Behavior, Fracture, and Microstructure Evolution of Austenitic Stainless AISI 316Ti Steel. Appl. Sci. 2021, 11, 3204. [CrossRef]

25. Qiao, G.Y.; Xiao, F.R.; Zhang, X.B.; Cao, Y.B.; Liao, B. Effects of contents of $\mathrm{Nb}$ and $\mathrm{C}$ on hot deformation behaviors of high $\mathrm{Nb}$ X80 pipeline steels. Trans. Nonferrous Met. Soc. China 2009, 19, 1395-1399. [CrossRef]

26. Rajput, S.K.; Chaudhari, G.P.; Nath, S.K. Characterization of hot deformation behavior of a low carbon steel using processing maps, constitutive equations and Zener-Hollomon parameter. J. Mater. Process. Technol. 2016, 237, 113-125. [CrossRef]

27. Li, H.Y.; Wei, D.D.; Hu, J.D.; Li, Y.H.; Chen, S.L. Constitutive modeling for hot deformation behavior of T24 ferritic steel. Comput Mater. Sci. 2012, 53, 425-430. [CrossRef]

28. Li, H.Y.; Hu, J.D.; Wei, D.D.; Wang, X.F.; Li, Y.H. Artificial neural network and constitutive equations to predict the hot deformation behavior of modified 2.25Cr-1Mo steel. Mater. Des. 2012, 42, 192-197. [CrossRef]

29. Wang, J.; Xiao, H.; Xie, H.; Xu, X.; Gao, Y. Study on hot deformation behavior of carbon structural steel with flow stress. Mater. Sci. Eng. A 2012, 539, 294-300. [CrossRef]

30. Wei, H.L.; Liu, G.Q.; Zhao, H.T.; Zhang, M.H. Effect of carbon content on hot deformation behaviors of vanadium microalloyed steels. Mater. Sci. Eng. A 2014, 596, 112-120. [CrossRef]

31. Mirzadeh, H.; Parsa, M.H.; Ohadi, D. Hot deformation behavior of austenitic stainless steel for a wide range of initial grain size. Mater. Sci. Eng. A 2013, 569, 54-60. [CrossRef]

32. Saadatkia, S.; Mirzadeh, H.; Cabrera, J.M. Hot deformation behavior, dynamic recrystallization, and physically-based constitutive modeling of plain carbon steels. Mater. Sci. Eng. A 2015, 636, 196-202. [CrossRef]

33. Abbasi, S.M.; Shokuhfar, A. Prediction of hot deformation behaviour of 10Cr-10Ni-5Mo-2Cu steel. Mater. Lett. 2007, 61, 2523-2526. [CrossRef]

34. Momeni, A.; Dehghani, K. Characterization of hot deformation behavior of 410 martensitic stainless steel using constitutive equations and processing maps. Mater. Sci. Eng. A 2010, 527, 5467-5473. [CrossRef]

35. Chen, J.; Liu, Y.; Liu, C.; Zhou, X.; Li, H. Study on microstructural evolution and constitutive modeling for hot deformation behavior of a low-carbon RAFM steel. J. Mater. Res. 2017, 32, 1376-1385. [CrossRef]

36. Cao, Y.; Di, H.; Misra, R.D.K.; Yi, X.; Zhang, J.; Ma, T. On the hot deformation behavior of AISI 420 stainless steel based on constitutive analysis and CSL model. Mater. Sci. Eng. A 2014, 593, 111-119. [CrossRef]

37. Churyumov, A.Y. Deformation and Fracture of $13 \mathrm{CrMoNbV}$ Ferritic-Martensitic Steel at Elevated Temperature. Phys. Met. Metallogr. 2019, 120, 1228-1232. [CrossRef]

38. Cao, Y.B.; Xiao, F.R.; Qiao, G.Y.; Zhang, X.B.; Liao, B. Quantitative research on effects of Nb on hot deformation behaviors of high-Nb microalloyed steels. Mater. Sci. Eng. A 2011, 530, 277-284. [CrossRef]

39. Gao, F.; Yu, F.X.; Liu, F.T.; Liu, Z.Y. Hot Deformation Behavior and Flow Stress Prediction of Ultra Purified $17 \%$ Cr Ferritc Stainless Steel Stabilized with $\mathrm{Nb}$ and Ti. J. Iron Steel Res. Int. 2015, 22, 827-836. [CrossRef]

40. Zeng, Z.; Chen, L.; Zhu, F.; Liu, X. Dynamic recrystallization behavior of a heat-resistant martensitic stainless steel $403 \mathrm{Nb}$ during hot deformation. J. Mater. Sci. Technol. 2011, 27, 913-919. [CrossRef]

41. Mehtonen, S.V.; Karjalainen, L.P.; Porter, D.A. Hot deformation behavior and microstructure evolution of a stabilized high-Cr ferritic stainless steel. Mater. Sci. Eng. A 2013, 571, 1-12. [CrossRef]

42. Churyumov, A.Y.; Khomutov, M.G.; Solonin, A.N.; Pozdniakov, A.V.; Churyumova, T.A.; Minyaylo, B.F. Hot deformation behaviour and fracture of 10CrMoWNb ferritic-martensitic steel. Mater. Des. 2015, 74, 44-54. [CrossRef]

43. Haj, M.; Mansouri, H.; Vafaei, R.; Ebrahimi, G.R.; Kanani, A. Hot compression deformation behavior of AISI 321 austenitic stainless steel. Int. J. Miner. Metall. Mater. 2013, 20, 529-534. [CrossRef]

44. Voyzelle, B.; Boyd, J.D. High-temperature deformation behaviour of Fe ${ }_{3}$ Al. Mater. Sci. Eng. A 1998, 258, 243-248. [CrossRef]

45. Churyumov, A.Y.; Pozdnyakov, A.V.; Churyumova, T.A.; Cheverikin, V.V. Hot plastic deformation of heat-resistant austenitic aisi 310s steel. Part 1. simulation of flow stress and dynamic recrystallization. Chernye Met. 2020, 2020, 48-55.

46. Ghadar, S.; Momeni, A.; Tolaminejad, B.; Soltanalinezhad, M. A comparative study on the hot deformation behavior of 410 stainless and K100 tool steels. Mater. Sci. Eng. A 2019, 760, 394-406. [CrossRef] 
47. Xiao, X.; Liu, G.Q.; Hu, B.F.; Zheng, X.; Wang, L.N.; Chen, S.J.; Ullah, A. A comparative study on Arrhenius-type constitutive equations and artificial neural network model to predict high-temperature deformation behaviour in $12 \mathrm{Cr} 3 \mathrm{WV}$ steel. Comput. Mater. Sci. 2012, 62, 227-234. [CrossRef]

48. Shaikh, A.; Churyumov, A.; Pozdniakov, A.; Churyumova, T. Simulation of the hot deformation and fracture behavior of reduced activation ferritic/martensitic 13CrMoNbV Steel. Appl. Sci. 2020, 10, 530. [CrossRef]

49. Mehtonen, S.V.; Karjalainen, L.P.; Porter, D.A. Modeling of the high temperature flow behavior of stabilized $12-27 \mathrm{wt} \% \mathrm{Cr}$ ferritic stainless steels. Mater. Sci. Eng. A 2014, 607, 44-52. [CrossRef]

50. Dub, V.; Churyumov, A.; Rodin, A.; Belikov, S.; Barbolin, A. Prediction of grain size evolution for low alloyed steels. Results Phys. 2018, 8, 584-586. [CrossRef]

51. Zhao, C.; Zhang, J.; Yang, B.; Li, Y.F.; Huang, J.F.; Lian, Y. Hot Deformation Characteristics and Processing Map of 1Cr12Ni2Mo2WVNb Martensitic Stainless Steel. Steel Res. Int. 2020, 91, 2000020. [CrossRef]

52. Yang, Y.; Li, T.R.; Jia, T.; Wang, Z.D.; Misra, R.D.K. Dynamic Recrystallization and Flow Behavior in Low Carbon Nb-Ti Microalloyed Steel. Steel Res. Int. 2018, 89, 1700395. [CrossRef]

53. Momeni, A.; Dehghani, K.; Keshmiri, H.; Ebrahimi, G.R. Hot deformation behavior and microstructural evolution of a superaustenitic stainless steel. Mater. Sci. Eng. A 2010, 527, 1605-1611. [CrossRef]

54. Ren, F.; Chen, F.; Chen, J.; Tang, X. Hot deformation behavior and processing maps of AISI 420 martensitic stainless steel. J. Manuf. Process. 2018, 31, 640-649. [CrossRef]

55. Ren, F.C.; Chen, J.; Chen, F. Constitutive modeling of hot deformation behavior of X20Cr13 martensitic stainless steel with strain effect. Trans. Nonferrous Met. Soc. China 2014, 24, 1407-1413. [CrossRef]

56. Liu, N.; Liu, Z.D.; He, X.K.; Yang, Z.Q.; Ma, L.T. Hot Deformation Behavior of SA508GR. 4N Steel for Nuclear Reactor Pressure Vessels. J. Iron Steel Res. Int. 2016, 23, 1342-1348. [CrossRef]

57. Jang, M.H.; Kang, J.Y.; Jang, J.H.; Lee, T.H.; Lee, C. Hot deformation behavior and microstructural evolution of alumina-forming austenitic heat-resistant steels during hot compression. Mater. Charact. 2017, 123, 207-217. [CrossRef]

58. Yang, P.R.; Cai, M.H.; Wu, C.F.; Su, J.H.; Guo, X.P. Strain-rate dependent hot deformation behavior and mechanism of interphaseprecipitated Ti-Mo-xNb steels: Physical modeling and characterization. Mater. Sci. Eng. A 2018, 729, 230-240. [CrossRef]

59. Singh, K.; Rajput, S.K.; Mehta, Y. Modeling of the hot deformation behavior of a high phosphorus steel using artificial neural networks. Mater. Discov. 2016, 6, 1-8. [CrossRef]

60. Lachtermacher, G.; Fuller, J.D. Back propagation in time-series forecasting. J. Forecast. 1995, 14, 381-393. [CrossRef]

61. Wan, Z.; Hu, L.; Sun, Y.; Wang, T.; Li, Z. Hot deformation behavior and processing workability of a Ni-based alloy. J. Alloys Compd. 2018, 769, 367-375. [CrossRef]

62. Churyumov, A.Y.; Khomutov, M.G.; Tsar'Kov, A.A.; Pozdnyakov, A.V.; Solonin, A.N.; Efimov, V.M.; Mukhanov, E.L. Study of the structure and mechanical properties of corrosion-resistant steel with a high concentration of boron at elevated temperatures. Phys. Met. Metallogr. 2014, 115, 809-813. [CrossRef]

63. Mandal, S.; Sivaprasad, P.V.; Venugopal, S.; Murthy, K.P.N. Artificial neural network modeling to evaluate and predict the deformation behavior of stainless steel type AISI 304L during hot torsion. Appl. Soft Comput. J. 2009, 9, 237-244. [CrossRef]

64. Zener, C.; Hollomon, J.H. Effect of strain rate upon plastic flow of steel. J. Appl. Phys. 1944, 15, 22-32. [CrossRef]

65. Li, J.; Zhao, G.; Ma, L.; Chen, H.; Li, H.; Zhang, W. Effect of copper element on hot behavior of 304L stainless steel. Mater. Tehnol. 2018, 52, 529-536. [CrossRef]

66. Zheng, Y.; Shen, W.; Zhu, L.; Guo, Z.; Wang, Q.; Feng, J.; Li, Y.; Cao, R.; Wu, J. Effects of composition and strain rate on hot ductility of Cr-Mo-alloy steel in the two-phase region. High Temp. Mater. Process. 2021, 40, 228-240. [CrossRef]

67. Zaitsev, A.; Arutyunyan, N. Low-carbon Ti-Mo microalloyed hot rolled steels: Special features of the formation of the structural state and mechanical properties. Metals 2021, 11, 1584. [CrossRef] 